tain Bluebirds, up from 35 last year (and compared to $3,8,12$ and 25, respectively, in the first 4 years). In addition, we had our first female Eastern Bluebird, mated to a male Mountain Bluebird, producing five healthy hybrid young. Due to a late spring and heavy spring rains, many nests were deserted and the average brood size for bluebirds was only 4.73, yet we banded a record 183 young Mountain Bluebirds plus the five hybrids mentioned.

Our Tree Swallows did well this year with an average brood size of 5.44 when banded. With increasing numbers of bluebirds and House Wrens, the latter up from a previous maximum of two to eight this year, the number of boxes used by Tree Swallows was down to 132 this year. House Sparrows, fortunately, dropped from 52 to 45 boxes.

Twenty-one boxes were used by two or more species during the season. One pair of Tree Swallows successfully raised five young and simultaneously fledged a young bluebird from an egg left by a Mountain Bluebird that had occupied the box before the swallows took over. In total, the Saskatoon Junior Natural History Society is pleased with results for the past 6 years and we look forward to a further increase in bluebird occupancy in 1975 .

\section{LANGHAM, SASKATCHEWAN BLUEBIRD PROJECT - 1974}

\section{by JACK KARGUT*}

This spring instead of the usual 10 boxes to the mile, we erected 12 boxes in one half mile as an experiment. The results speak for themselves: four pairs of Mountain Bluebirds, eight pairs of Tree Swallows and one pair of House Wrens, including a pair of bluebirds that followed a swallow nesting - all in a half mile!

*Box 92

Langham, Salskatchewan

SOK 2LO
Efforts to date:

Nesting boxes added - New

-Replacements 21

Total boxes erected (1971-1974) 452

Additional area covered 1974:

No. 5 Highway, Denholm to

Battleford completed.

Sandhills area extended to Asquith grid-road.

Grid-road north to correction line (approx. 6 miles).

Park Municipal Pasture (approx. 5 miles).

Upper approach to Borden bridge.

South and west along N. Saskatchewan River (approx. 5 miles).

1974 Results:

Mountain Bluebird

93 pairs

(440 eggs and young)

Tree Swallow 268 pairs

(1459 eggs and young)

House Sparrow

27 pairs

House Wren

10 pairs

Flicker

Starling

2 pairs

Vacant

1 pair

Boxes unaccounted for

31

20

\section{WESTERN TANAGER SIGHTING IN MANITOBA}

\author{
by CALVIN CUTHBERT*
}

On June 26, 1973, while participating in Breeding Bird Surveys in the Carberry Spruce Woods area of Manitoba I had the good fortune to observe a male Western Tanager.

At 6:30 a.m. I was about to complete the last grid line of a 20-acre plot located 20 miles southeast of Carberry. A series of hoarse warbling notes, however, coming from inside a nearby stand of mature white spruce caught my attention. The song was unfamiliar to me and, as I had not heard

${ }^{*}$ R.R. 1, Box 59,

Portage La Prairie, Manitoba. 
it on previous morning visits to the plot, I decided to check it out. Upon my quiet approach to the spruce stand, the singing stopped and much to my surprise out flew a male Western Tanager. The bird flew a distance of about 60 yards and landed on the top of a white spruce. Upon focusing my $7 \times 35$ power binoculars on the bird, its identity was unmistakable. Its dominant yellow colouring with black tail and upper back and dark wings with light yellow wing bars was quite apparent. The red forehead on its otherwise yellow head clinched identification. The bird remained on the top of the tree for about 1 minute, sang briefly and then flew off. I did not see it again.

There have been several other recorded sightings of Western Tanagers in Manitoba. Records from the late A. J. Lawrence's columns of "Chickadee Notes" in the Winnipeg Free Press indicate that pairs of birds were seen at St. Vital, Brandon, and Starbuck in June, 1933, July, 1938, and early July, 1963, respectively. Locations of single sightings include Ponemah and Winnipeg. Godfrey (1966. The Birds of Canada) however, makes no mention of the status of this species in Manitoba.

\section{SASKATCHEWAN CHRISTMAS BIRD COUNT 1974}

List the number of each bird species seen on the one best day from Saturday, December 14 , through Tuesday, December 31, 1974. If your chosen day is snowed or frozen out, you may take it New Year's Day. See the June, 1974 Blue Jay for examples and details. Send reports as soon as possible and by January 10, 1975, at the latest, to Mrs. Mary Houston, 863 University Drive, Saskatoon, Sask., S7N 0J8.

\section{HELP A U.S. REFUGE FOR SANDHILL CRANES}

THE FACTS: Shallow submerge sandbars with adjacent wet meadow and nearby croplands make the Grea Bend area of the Platte River in cen tral Nebraska a uniquely-ideal restin. and feeding area for sandhill crane Each spring about $80 \%$ of the tota mid-continental population of sandhil cranes $(250,000$ birds) converge on th area during their annual northwar migration. The area also is used $b$ Canada geese, pintail and mallar ducks and endangered bald eagles an whooping cranes. The U.S. Fish an Wildlife Service proposes to establis a national wildlife refuge in the area encompassing 11 miles of Platte Rive flood plain (15,000 acres) or one-fifth of the traditional sandhill cran habitat. THE CRISIS: The refuge i opposed by many local landowners developers, and supporters of the still pending Mid-State Reclamatiol Project. Meanwhile, crane habitat i being lost. WHAT YOU CAN DO Write Rogers C. B. Morton, Secretary of the Interior, Washington, D.C 20240. Advise him of your interest ir cranes and urge him to support the refuge, and abandon the Mid-State project or modify it to protect water fowl. Send copies to Mme. Jeanne Sauvé, Minister, Environment Canada Place Vincent Massey Bldg., Hull Quebec, and to S.N.H.S., Box 1321 Regina, Saskatchewan, S4P 3 B8 (Modified from National Wildlife).

\section{PRAIRIE NEST RECORD SCHEME}

Will anyone with nest records for 1974 or earlier please send them by January 3, 1975, to:

H. W. R. Copland,

Manitoba Museum of

Man and Nature,

190 Rupert Avenue,

Winnipeg, Manitoba,

R3B ON2.

A summary will then be prepared for contributors and interested persons. 